\title{
Intellectual Property Issues in Enterprise Science and Technology Cooperation
}

\author{
Zhu Dongyun \\ School of Public affairs, University of Science \& Technology of China.
}

\begin{abstract}
Open innovation has become the mainstream innovation paradigm of enterprises since its introduction, which must have a platform for knowledge sharing and open communication to achieve long-term development. The attribution and protection of intellectual property rights must be involved in the cooperation among enterprises in foreign scientific and technological cooperation and other innovation entities. This study initially categorizes the cooperation models among enterprises in Anhui Province and other innovation entities under open innovation. Then, the study summarizes the characteristics and applicable objects of each model. Combined with specific laws and regulations, the current ownership and the existing deficiencies of intellectual property in Anhui Province are discussed. Moreover, the study classifies the dilemma of intellectual property income distribution and proposes specific countermeasures. Simultaneously, the study explores the current existence of intellectual property protection in Anhui Province with the revised "Promotion of the Transformation of Scientific and Technological Achievements Law" as the background. Finally, this study suggests perfect measures from five aspects, namely, strengthening the construction of laws and regulations, increasing innovation investment, promoting result conversion mechanism, improving the enterprise-based assessment system, and cultivating intermediary institutions. The objective is to promote the healthy development of Anhui's intellectual property system.
\end{abstract}

Keywords: open innovation, cooperation mode, ownership of property rights, income from property rights, protection of property rights

DOI: $10.7176 / \mathrm{EJBM} / 12-27-08$

Publication date:September $30^{\text {th }} 2020$

\section{Introduction}

The traditional closed innovation theory holds that the key to achieve and maintain the core competitiveness of an enterprise is to use its own resources for internal research and development (R\&D). An enterprise can obtain core technologies inimitable by competitors and convert such technologies into products to win the market and customers through internal R\&D. Simultaneously, an enterprise continues to update its own core technology through internal innovation to maintain its competitive advantage. For instance, a group of technology-based enterprises with strong resources, such as Xerox and IBM, gained competitive advantages in the market in the middle of the last century. However, the entry of several emerging companies, such as Microsoft and Apple, had brought unprecedented pressure to leaders in the traditional industry by the end of the 20th century. These companies often do not have a strong scientific research foundation. They carry out technological development through various methods, such as introduction and cooperation, and redevelopment on the basis of some original foreign technologies. Rapidly developed new products occupied the market and brought considerable profits to the enterprise, which is an intellectual property change brought about by open innovation.

An enterprise is the most important innovation subject. Research on knowledge sharing and intellectual property issues in enterprise open innovation will help to further promote the development of open innovation in practice and will be more conducive to the innovation subject to enhance innovation capabilities and performance. We need to clarify the model of scientific and technological cooperation between the enterprise and the outside world to formulate intellectual property countermeasures under different models and analyze the intellectual property issues in open innovation.

\section{Model of enterprise's foreign scientific and technological cooperation}

At present, the classification of open innovation cooperation models has no unified conclusion. This study believes that when dividing the cooperation model, we should focus on the following aspects: The cooperation model embodies (1) the distribution of revenue, (2) the organizational system of cooperation, and (3) the risk-sharing method. This study categorizes the enterprise's open independent innovation stakeholder cooperation mode into four modes, namely, knowledge trading, commissioned R\&D, joint investment cooperative R\&D, and collaborative cooperative R\&D.

\subsection{Knowledge trading model}

The knowledge trading model is a fast and simple way of transferring knowledge or technology mainly through market trading. That is, an enterprise can acquire the knowledge it hopes to acquire by purchasing the technology and patents of other enterprises or scientific research institutions at one time. This knowledge trading model is a 
simple and low-cost technology acquisition method because establishing and managing a cooperative organization are not necessary. This model is a relatively common form of cooperation, and acquiring technology in this way does not require high internal technology. Thus, this model is conducive to the adoption of low-tech companies and can effectively reduce the risk of product development.

However, this method has also evident disadvantages. First, whether the knowledge acquired through purchase can create benefits for the enterprise or how much benefit is created depends on the ability of the enterprise to digest and absorb new technologies. Second, companies must pay extra costs, such as technical analysis and price evaluation costs, before purchasing the technology. Last, the technology acquired through purchase cannot become the core technology of an enterprise.

\subsection{Commissioned R\&D mode}

The commissioned R\&D mode refers to the relationship between the enterprise and other institutions or organizations with strong R\&D capabilities when their R\&D capabilities are insufficient. The enterprise generally funds this mode to entrust the institution to develop the technology required by the enterprise. In this model, the R\&D institution must have a strong scientific research capability and level compared with the enterprise, and no competitive relationship must exist with the commissioned enterprise.

The advantage of this model is that companies can obtain patents and technologies tailored to their own circumstances. Moreover, once the R\&D is successful, competitors cannot easily imitate this technology that can be used as the core technology of the company. However, this model requires sufficient information sharing between enterprises and R\&D institutions, and the former should have a certain level of technology. In addition, the most critical point is how to prevent the "moral hazard" in the principal-agent relationship of R\&D institutions due to the uncertainty of technological innovation.

Through the actual investigation, Guo Xiaochuan found that the commissioned R\&D mode in the relationship among enterprises, universities, and research institutes is currently the most adopted model. Universities and research institutes have stronger R\&D capabilities than enterprises, but they are not familiar with the market. Hence, they are usually reluctant to take the risks caused by the failure of the conversion of research results but are willing to conduct research with peace of mind. For the enterprise, the enterprise hopes to obtain full ownership of the innovation achievements and does not want the universities to participate in the benefits of future scientific research achievements transformation.

\subsection{Cooperative R\&D model}

In the cooperative $R \& D$ mode, the enterprise cooperates with other institutions or enterprises and jointly invests resources including capital, manpower, and technology for R\&D. The parties of the cooperation share funds, technology, human resources, risks, and profits through shared entity control. In this model, the high degree of interest binding makes the parties of the cooperation strongly dependent on each other. This type of cooperation is more long-term and stable than commissioned R\&D and knowledge trading models. Moreover, this kind of capital investment and joint management can enhance the trust between partners, which can effectively eliminate opportunistic behavior in cooperation.

However, in this model, all parties of the cooperation must have a considerable basis of trust and benefit from the results of joint development. The mode of cooperation can often achieve a win-win result, but the interests of all parties must be properly coordinated to maintain the long-term stability of cooperation.

\subsection{Collaborative R\&D model}

The collaborative R\&D model is an advanced form of cooperative R\&D model, which is mainly produced in a group of enterprises with close interest relations (e.g., various enterprises in the supply chain). Collaborative R\&D in the supply chain refers to the joint R\&D mode of coordination and cooperation between each node enterprise in the supply chain to improve the overall competitiveness of the supply chain. Each node enterprise forms a networked alliance through company agreements or joint organizations. In this collaborative network, suppliers, manufacturers, distributors, and customers can dynamically share information, work closely together, and move toward a common goal.

The main difference between this and other models is that under the collaborative R\&D model, companies no longer aim to maximize their own interests as the basis for corporate decision-making. All enterprises are committed to achieve the overall optimal supply chain on the basis of information sharing and make coordinated decisions after communicating with each other. This action addresses the low overall performance of the supply chain caused by decentralized decision-making of each node enterprise simply to maximize its own interests.

\section{Attribution of intellectual property rights and existing problems}

The current practice in the attribution of intellectual property rights for open innovation follows the provisions of national laws. The general principle is that the parties have autonomy and contract priority, except for national 
security, national interests, and major social and public interests, which are owned or compulsorily licensed by the state. Table 1 shows the situation of intellectual property rights belonging to the state (society), units, and individuals under open innovation in conjunction with relevant legal provisions.

Table 1: Relevant legal provisions for the ownership of intellectual property

\begin{tabular}{|c|c|c|}
\hline & $\begin{array}{l}\text { Ownership of } \\
\text { property rights }\end{array}$ & Laws involved \\
\hline \multirow{3}{*}{$\begin{array}{l}\text { Country or } \\
\text { socially } \\
\text { owned }\end{array}$} & $\begin{array}{l}\text { State ownership of } \\
\text { intellectual property }\end{array}$ & Article 20 of the "Science and Technology Progress Law" \\
\hline & $\begin{array}{l}\text { State enforcement } \\
\text { rights for intellectual } \\
\text { property }\end{array}$ & $\begin{array}{l}\text { Article } 20 \text { of the "Science and Technology Progress Law"; Article } 11 \\
\text { of the "Law on the Transformation of New Scientific and } \\
\text { Technological Achievements" }\end{array}$ \\
\hline & $\begin{array}{l}\text { The right to use the } \\
\text { intellectual property } \\
\text { of the public }\end{array}$ & $\begin{array}{l}\text { Articles } 22,23,40 \text {, and } 44 \text { in the Copyright Law; Articles } 16 \text { and } 17 \\
\text { of the Computer Software Protection Regulations; Articles } 48-51 \text { of } \\
\text { the Patent Law; Articles of the Regulations for the Protection of } \\
\text { Topographies of Integrated Circuits Articles } 23-25 \text {; Article } 10 \text { of the } \\
\text { Regulations on the Protection of New Varieties of Plants, etc. }\end{array}$ \\
\hline \multirow{3}{*}{$\begin{array}{c}\text { Unit } \\
\text { ownership }\end{array}$} & $\begin{array}{l}\text { The law stipulates } \\
\text { that ownership } \\
\text { belongs to the unit }\end{array}$ & $\begin{array}{l}\text { Article } 20 \text { of the Science and Technology Progress Law; Copyright } \\
\text { Law (Articles } 11 \text { and 16); Computer Software Protection Regulations } \\
\text { (Article 13); Article } 7 \text { of the New Plant Variety Protection } \\
\text { Regulations; Knowledge of Higher Education Regulations on the } \\
\text { Protection of Property Rights (Article 8); Article } 6 \text { of the Patent Law, } \\
\text { etc. }\end{array}$ \\
\hline & $\begin{array}{l}\text { The contract } \\
\text { stipulates that } \\
\text { ownership belongs to } \\
\text { the unit }\end{array}$ & $\begin{array}{l}\text { Article } 6 \text { of the Patent Law; } \\
\text { Article } 7 \text { of the Regulations on the Protection of New Varieties of } \\
\text { Plants; Article } 12 \text { of the Regulations on the Protection of Computer } \\
\text { Software; Article } 17 \text { of the Copyright Law; Article } 19 \text { of the Law on } \\
\text { the Transformation of New Scientific and Technological Achievements }\end{array}$ \\
\hline & The joint possession & $\begin{array}{l}\text { Article } 340 \text { of the Contract Law; } \\
\text { Article } 8 \text { of the Patent Law }\end{array}$ \\
\hline \multirow{2}{*}{$\begin{array}{l}\text { Personally } \\
\text { owned }\end{array}$} & $\begin{array}{l}\text { The law stipulates } \\
\text { that ownership } \\
\text { belongs to individuals }\end{array}$ & $\begin{array}{l}\text { Article } 20 \text { of the "Science and Technology Progress Law"; } \\
\text { "Patent Law"; } \\
\text { Regulations on the Protection of Topographies of Integrated Circuits; } \\
\text { Regulations on the Protection of New Varieties of Plants; } \\
\text { "Copyright Law," etc. }\end{array}$ \\
\hline & $\begin{array}{l}\text { The contract } \\
\text { stipulates that } \\
\text { ownership belongs to } \\
\text { individuals }\end{array}$ & $\begin{array}{l}\text { Article } 6 \text { of the Patent Law } \\
\text { Article } 7 \text { of the Regulations on the Protection of New Varieties of } \\
\text { Plants and Article } 17 \text { of the Copyright Law } \\
\text { Article } 19 \text { of the "New Technology Achievements Transformation } \\
\text { Law" }\end{array}$ \\
\hline
\end{tabular}

\subsection{Intellectual property belongs to the country}

On the one hand, intellectual property is a very monopolistic but restrictive private right because the balance of individual interests, social interests, and collective interests must be considered. On the other hand, open innovation is the only way for Anhui Province to implement innovation-driven development. Therefore, their public interests must be emphasized while protecting the intellectual property interests of all parties to cooperative innovation.

2.1.1 State ownership of intellectual property

Article 20 of the "Science and Technology Progress Law" stipulates that "The invention patent rights, computer software copyrights, integrated circuit layout design rights and new plant varieties formed by science and technology fund projects or science and technology plan projects established with financial funds, except for those involving national security, national interests, and major social and public interests, authorizing project undertakers to obtain these rights according to law." This notion shows that under certain special circumstances, state-funded scientific research projects involving national security, national interests, and the public interest of society improve the competitiveness of enterprises. Here, two issues must be resolved. First, the identification system of national security, national interests, and major social and public interests needs to be clarified. Using the "national interest, social public interest" to seek illegitimate rights or interests must be avoided because the identification process is too complicated. Moreover, the innovation enthusiasm of the main body of innovation is suppressed. Second, certain situations that do not involve national security, national interests, or major social and public interests but 
are not suitable for granting intellectual property rights to project undertakers must be elucidated.

2.1.2 State's right to enforce intellectual property rights

Article 20 of the "Science and Technology Progress Law" stipulates that when the intellectual property rights of state-sponsored scientific research projects belong to the unit, the state can implement these two situations for free. First, the unit has not implemented it within a reasonable period. It can be implemented free of charge or can be allowed to be implemented by others with or without compensation. Second, the state can implement it free of charge for national security, national interests, and major social and public interests, and others are also allowed to implement it with or without compensation (the state "right to intervene"). Article 11 of the 2015 Law on Promoting the Transformation of Scientific and Technological Achievements (Amendment) (hereinafter referred to as the "New Science and Technology Achievements Transformation Law") stipulates that "The undertakers of scientific and technological projects established with financial funds shall submit relevant scientific and technological reports in accordance with the regulations in a timely manner, and transfer scientific and technological achievements and related intellectual property information to the scientific and technological achievements information system." The six cases of countries stipulated in Article 12 realizing the transformation of achievements through government procurement, R\&D funding, and publishing industrial technology guidance catalogs are too principled. The indicators of "significantly improve the technical level and economic benefits" and other issues need to be determined in practice with specific cases.

2.1.3 Public's right to use intellectual property or compulsory license

Generally, the ownership or application right of intellectual property rights in cooperative innovation belongs to the individual or unit of completion. However, the public cannot be prohibited from using its achievements reasonably and properly. Such legal provisions are mainly found in Articles 22, 23, 40, and 44 of the Copyright Law; Articles 16 and 17 of the Computer Software Protection Regulations; Articles 48 to 51 of the Patent Law; Articles 23-25 of the Regulations for the Protection of Graphic Design; Article 10 of the Regulations for the Protection of New Varieties of Plants, etc.

\subsection{Intellectual property rights belong to the unit}

2.2.1 Law stipulates that intellectual property rights belong to the unit

(1) State-funded projects. Intellectual property rights formed by state-funded projects that do not involve national security, national interests, or major social and public interests are acquired by the project undertaker. Project undertakers generally refer to academic and research institutions participating in industry-university-research cooperation. The legislation, such as Article 20 of the "Science and Technology Progress Law," is conducive to mobilizing the enthusiasm of scientific research institutions and scientific and technological personnel. Moreover, the legislation is conducive to the transformation of scientific and technological achievements.

(2) Job achievements. With regard to the attribution of the rights to job achievements, China's legislation stipulates three situations. First, the right to apply for patents for non-duty inventions and creations belongs to the inventor. Second, when performing the tasks of the unit, the right to job results belongs to the unit, such as "The Copyright Law" (Articles 11 and 16), the Computer Software Protection Regulations (Article 13), the New Plant Variety Protection Regulations Article 7, and the "Administrative Provisions on the Protection of Intellectual Property Rights in Colleges and Universities" (Article 8). Third, the attribution of certain job achievements and the right to the achievement of the job invention created by using the unit's material and technical conditions and the agreement between the unit and the inventor shall be applied preferentially. No agreement is attributed to the unit, such as "Computer Software Protection Regulations" Article 12.

The third paragraph of Article 6 of the Patent Law stipulates that "In the invention and creation completed by using the material and technical conditions of the unit, the unit has a contract with the inventor or designer to make an agreement on the right to apply for a patent and the ownership of the patent right, and the agreement shall be followed." The implication is that if no agreement exists, then the provisions of the first paragraph of this article shall apply. "The right to apply for a patent for a service invention shall belong to the unit; after the application is approved, the unit shall be the patentee." The problem is that the principle of "contracted priority" may be abused in practice to damage the interests of the unit, resulting in the loss of state-owned assets. The rights enjoyed by the unit must be further stipulated when the relevant intellectual property rights are granted to the inventor by contract and the rights enjoyed by the inventor when the relevant intellectual property rights belong to the unit. This measure is to protect the interests of the unit and the inventor. The former is mainly represented as the unpaid general implementation right, whereas the latter is mainly represented as the right to request remuneration. 2.2.2 Contract stipulates that the intellectual property rights belong to the unit Article 6 of the "Patent Law" stipulates that, for an invention created by using the material and technical conditions of the unit, the unit has a contract with the inventor or designer to make an agreement on the right to apply for a patent and the ownership of the patent right. By agreement, the patent right belongs to the unit. Article 7 of the Regulations for the Protection of New Varieties of Plants, Article 12 of the Regulations for the Protection of Computer Software, Article 17 of the Copyright Law, and Article 19 of the Law on the Transformation of New 
Scientific and Technological Achievements have similar provisions.

\subsubsection{Common issues of intellectual property rights}

Given that open innovation emphasizes cooperation, common property is inevitable. In this regard, Article 340 of the "Contract Law" stipulates that "The invention and creation completed through cooperative development, unless otherwise agreed by the parties, the right to apply for a patent belongs to the parties to the cooperative development." Article 8 of the "Patent Law" has similar provisions. Different from the principle of "Statutory takes precedence over agreement" adopted by intellectual property attribution for setting up scientific research projects using financial funds, in principle, the attribution of intellectual property rights among the parties to the cooperation is prioritized. Moreover, mutual ownership is a legal supplement. As for how to cooperatively develop and jointly exercise intellectual property rights, further legislation is essential to clarify or improve the contract to be resolved.

\subsection{Intellectual property rights belong to individuals}

2.3.1 Law stipulates that intellectual property rights belong to individuals

(1) State-funded projects. As mentioned above, according to Article 20 of the "Science and Technology Progress Law," "The right to knowledge achievements formed by science and technology fund projects or science and technology plan projects established with financial funds is generally obtained by authorized project undertakers according to law." The "project undertaker" mainly refers to the enterprises and institutions undertaking the project, such as scientific research institutions, universities, and enterprises, and individuals are not excluded. For example, several scientific research personnel jointly undertake a scientific research project and become the project undertaker. Therefore, the intellectual property rights of state-funded projects can be owned by individuals to give play to the autonomy, enthusiasm, and creativity of scientific and technological personnel.

(2) Non-service inventions and creations. The Patent Law stipulates that for a non-service invention creation, the right to apply for a patent belongs to the inventor or designer. After the application is approved, the inventor or designer shall be the patentee. No unit or individual may suppress the inventor or designer's right to apply for a patent for a non-service invention. The Regulations on the Protection of Layout Designs of Integrated Circuits and the Regulations on the Protection of New Varieties of Plants have similar provisions. In the territories of the Copyright Law, in most cases, the copyright belongs to individuals.

2.3.2 Contract stipulates that the intellectual property rights belong to the individual

Article 6 of the "Patent Law" stipulates that if an entity creates an invention or creation by using the material and technical conditions of the unit, and the unit has a contract with the inventor or designer and agrees on the right to apply for a patent and the ownership of the patent right, then the agreement shall be followed. This notion shows that the individual employees make use of the material and technical conditions of the unit to create inventions and creations. The law allows employees to agree with the unit, providing the unit a certain amount of material compensation. Furthermore, the individual employee obtains patent rights, which is conducive to mobilizing the enthusiasm of employees for invention and creation. Article 7 of the "Regulations for the Protection of New Varieties of Plants" and Article 17 of the "Copyright Law" stipulate that individuals can contract to enjoy the right of intellectual achievements formed by entrusted breeding, cooperative breeding, and entrusted works. Article 19 of the "New Technology Achievements Transformation Law" provides additional cooperative and innovative intellectual property rights to individual enjoyment, opening a legislative breakthrough.

\section{Dilemma and countermeasures of the intellectual property income distribution 3.1 Dilemma of the intellectual property income distribution}

3.1.1 Distribution of intellectual property interests lacks basis, and the content of the agreement lacks operability In the determination of the basis for the benefit sharing of all parties, the intellectual property benefit-sharing agreement in open innovation is an important content. However, this topic has not attracted due attention, resulting in a lack of basis for the distribution of intellectual property benefits. The distribution of intellectual property rights is relatively simple in terms of agreement content and does not have strong operability. In principle, the attribution of intellectual property rights and the distribution of benefits should be carried out according to the agreement. Enterprises and universities in Anhui Province attach great importance to open innovation and use this cooperative relationship to win government funding for science and technology projects. However, they have neglected the allocation of intellectual property interests among open innovation members. Hence, these members sign an intellectual property agreement too hastily, ignoring the operability of the agreement itself, leading to great hidden danger for the treatment of intellectual property among the main bodies. The principle of "who invests and who gains" is widely applied in my country's open innovation. In actual society, the income content is not only unclear but also lacks a factual basis, and this income content cannot solve the problem of "who owns."

3.1.2 Rights and obligations of members have not received enough attention

Promoting the transfer of knowledge among organizations is one of the important functions of cooperative innovation in open innovation. Knowledge sharing and knowledge transfer are necessary processes in cooperative innovation. Before members join the open innovation, their acquired technology and background are the basis for 
a smooth and rapid flow of knowledge among the cooperative members, which largely determines the success or failure of innovation. Members with a high-knowledge technology background will naturally have a greater role than those with a low-knowledge technology background. Their interests and obligations and the distribution of intellectual property rights are also different. However, at present, the distribution of intellectual property rights in my country's open innovation has not paid enough attention to the rights and obligations of members, and the state is chaotic.

3.1.3 Lack of regulations on the use and transfer of intellectual property

"Joint development, complementary advantages" is a highly evident feature of open innovation, but people often pay additional attention to "benefit sharing, risk sharing" of open innovation. Currently, many open innovation alliances focus on realizing the reciprocal technology transfer within the alliance between universities and enterprises. However, the intellectual property rights acquired through reciprocity among enterprises or between enterprises and universities are less involved in the distribution of innovation intellectual property interests. In open innovation, not every participant can have a major role in intellectual property rights, and some do not even participate in the process of obtaining intellectual property rights. What kind of benefits should they obtain in open innovation and make important contributions? In the current distribution of intellectual property interests, no specific provisions on the distribution of benefits that should be obtained by the main body of the company exist. In addition to internal, the principles for the external transfer and use of intellectual property rights are not reflected in the current intellectual property rights distribution mechanism.

\subsection{Countermeasures for the dilemma of the intellectual property income distribution}

\subsubsection{General principles for determining the attribution of intellectual property rights}

Regarding the ownership of the innovation achievements, the cooperation partners should reach an agreement before the establishment of open innovation. The subject of innovation should try to avoid common phenomena in the attribution of scientific research results, and allowing each member to own innovation achievements separately is better. In the actual application field, innovation achievement is beyond the scope of enterprise utilization. If the main development task of the innovation achievement is completed by the university, then the owner of the intellectual property right of the scientific research achievement should be the university, and the right to use the scientific research achievement can be transferred to the enterprise for exclusive use. However, if the enterprise's confidential information is included in the innovation achievements, then the ownership of the innovation achievements should be solely enjoyed by the enterprise.

Some innovative achievements are also unpredictable, and ownership of this part can be allocated to the actual research or use a unit of the project under the agreed premises. If the actual research or user unit cannot be determined during this process, then the part of the contribution should be the concentration point of the ownership of each party. In addition, the parties should not be independent in the overall use of intellectual property rights. Each member may elect a co-owner to apply for and maintain intellectual property rights to overcome the disadvantages of maintaining the rights inherent in shared intellectual property rights. However, this co-owner shall cover the cost of the application for intellectual property rights. When using intellectual property rights, the joint owners may allow others to use the intellectual property rights with the mutual consent of the member units. However, the benefits obtained in this use process shall belong to all member units.

3.2.2 Clarification of the rights and obligations of different subjects

The subject of open innovation must fulfill certain obligations or enjoy certain rights in the process of acquiring intellectual property rights or failing to acquire intellectual property rights. These views should be clearly reflected in the intellectual property rights distribution mechanism in open innovation. When universities and scientific research institutions are the owners of intellectual property rights, the main body of open innovation needs to undertake the following obligations: intellectual property rights must be properly managed to avoid losses due to management problems. In the R\&D of scientific research results, confidential information of other members of open innovation also needs to be included in the strict protection of universities and scientific research institutions. If the research results of the cooperative members have not been made public, the intellectual property rights owner in open innovation should ensure that the rights are used within the scope of the cooperation charter.

If the owner of the intellectual property rights is an enterprise, the enterprise needs to strictly manage and implement the intellectual property rights obtained from the cooperative research project. In addition, the enterprise must provide certain economic compensation to the members who have made major contributions. Members who have not obtained intellectual property rights may enjoy certain rights. For example, when the member greatly invests in intellectual property for $R \& D$, for non-exclusive use rights, the member can sign a contract to use the intellectual property preferentially or free of charge.

3.2.3 Formulation of guidelines for the transfer and use of intellectual property

In the process of transfer, no member shall transfer intellectual property rights alone, other members must be informed in advance, and the rights can only be transferred with the consent of all members. In the process of transfer, the rights and obligations of intellectual property rights are transferred together, such as the obligation to 
promote and industrialize intellectual property rights and enjoy the benefits brought by intellectual property rights. In the process of transferring intellectual property rights, reasonable economic benefits must be compensated according to the contributions made by members.

Regarding the confidentiality of innovation achievements, all or each member can formulate regulations that they all abide by in advance. Regardless of whether innovation achievements must be confidential or keeping confidentiality, all parties must strictly abide by the agreement. When preparing to publish innovations, one must follow the principle of not damaging the legitimate rights and interests of other members. Once a member's interests are harmed, the member can raise objections and negotiate again until a reasonable plan is found.

In terms of the use of scientific research results, the requirements are different depending on the nature of the use. If applied in the research field, the terms must not significantly affect the interests of other innovative members If applied in the business field, when a member applies the term to a certain field, other members must also apply to other fields to avoid damaging the interests of members.

\section{Countermeasures for intellectual property protection in enterprises' foreign cooperation}

\subsection{Problems existing in intellectual property protection in enterprises' foreign cooperation}

The problem of lagging in the construction of related laws and regulations is manifested as follows. On the one hand, the scope of intellectual property rights is relatively wide. Different types of intellectual property rights are under the jurisdiction of different departments, bringing certain difficulties to the formulation of unified laws and regulations. On the other hand, the work done by Anhui Province in the construction of relevant laws and regulations is inefficient. In addition, existing laws and regulations still have many deficiencies, such as insufficient publicity of the existing laws and regulations by the government and insufficient enforcement of relevant laws and regulations.

Enterprises do not pay enough attention to patents. Unlike the investment in production and sales of enterprises, the effect of which can often be rapidly seen. The investment risk of enterprises in patent development is relatively large, specifically technological innovation, and the probability of failure is usually high. Bearing the risk of failure is difficult for small- and medium-sized enterprises. A few large enterprises have established patent institutions and organizations and corresponding internal rules and regulations, but the rules are often not implemented, flowing in form. The development of patented technology requires enterprises to have considerable technical capabilities.

The transformation of patents in universities and research institutes has difficulties. Most of the patents owned by universities and research institutes are in a dormant state and have not been transformed into real productivity. This case is mainly because the patent achievements of universities and research institutes are generally in the laboratory stage. Moreover, a considerable distance still exists from industrialization and entering the market, or the results are often a core technology and not mature product one. Making qualified products still require a long process of secondary development, system integration, and product improvement, which needs considerable economic and technical investment. Given that the evaluation standard of their work is the technical results of their output, the relevant personnel of universities and research institutes often lack the willingness to pay attention to the follow-up work.

The evaluation mechanism in the transformation of scientific and technological achievements is not flexible. According to the regulations on the management of state-owned intangible assets, the transformation of stateowned intangible assets requires value evaluation. In addition, enterprises need to formulate a scientific and reasonable review mechanism. However, companies often emphasize the protection of intangible assets, such as intellectual property rights, and ignore the cost and investment of maintaining these intangible assets because they are concerned about the loss of state-owned intangible assets. Many companies clearly stipulate that patent transfer, licensing, and waiver are not allowed. Enterprises that allow patent licensing also have to repeatedly evaluate the value of patents and need to go through multiple levels of approvals led by multi-level departments. The evaluation value of patents is often higher than the market value due to the long approval time, which will lead to the loss of the market timing and difficulty in the conversion of results. The inflexibility of the review mechanism makes realizing the transformation of scientific and technological achievements difficult.

\subsection{Countermeasure suggestions for intellectual property protection}

4.2.1 Acceleration of the construction of laws and regulations on the protection of intellectual property rights and an increase in law enforcement

On the one hand, local regulations and policies must be established and improved for the protection of intellectual property rights. Moreover, the obstacles should be cleared to open innovation in the original legal system, and the current intellectual property system must be improved. For example, the relevant parts of new varieties, such as biotechnology, animals, and plants, are included in the scope of protection of the patent law, to broaden the scope of protection of patents. Provisions are made for the status and responsibilities of newly emerging network entities, namely online information and service providers in the copyright law. 
On the other hand, the construction of IPR administrative enforcement teams must be strengthened. In addition, various forms of training and seminars should be promoted, and the quality of IPR administrative enforcement personnel must be improved. The supervision of key industries should be highlighted to conduct antipiracy and anti-counterfeiting special governance actions. Various infringement and piracy acts that endanger the public interest must be cracked down. Establishing an inter-departmental intellectual property law enforcement collaboration mechanism is essential to ensure a good connection between administrative law enforcement and justice. Establishing and improving a communication mechanism for intellectual property protection with intellectual property owners are also necessary. Through regular communication, understanding the opinions and suggestions of companies and patentee, trademarks owners, copyright owners on combating counterfeit and shoddy goods, and protecting intellectual property are all crucial to solve problems promptly and safeguard the legitimate rights and interests of intellectual property rights holders effectively.

4.2.2 Smooth results conversion mechanism

The transformation rate of innovation achievements in Anhui Province has long been at a low level, and many scientific research achievements stay in the laboratory or are only published in the form of papers. For a smooth results transformation mechanism, establishing and improving the cooperation system of industry, university, and research institute are necessary. First, cooperation channels must be broadened extensively. On the one hand, cooperation through joint $\mathrm{R} \& \mathrm{D}$, technical consulting training, and sharing research resources must be strengthened, and cooperation channels from the level of sharing should be expanded. On the other hand, universities, research institutes, and enterprises can be encouraged and guided to jointly establish laboratories, or through a joint venture, investment, equity participation, and other ways to obtain an alliance with enterprises.

Second, the government actively creates a cooperative environment. On the one hand, government departments should attach great importance to the establishment of an industry-university-research cooperation mechanism. Setting up a special leading institution is recommended to strengthen the leadership of industryuniversity-research cooperation, timely study the outstanding and difficult problems in the cooperation process, and propose solutions. Furthermore; a provincial special fund for industry-university-research cooperation should be established and increased in proportion to the provincial enterprise technology innovation special fund annually. On the other hand, we must increase the construction of risk investment institutions and improve the risk investment mechanism. The government establishes a venture capital guidance fund. In accordance with the principles of "government capital guidance, social capital participation, expert management, and market-oriented operation", attracting social capital, participating in technological innovation and venture capital investment, and establishing several venture capital companies are essential.

4.2.3 Establishment and improvement of an enterprise-led review mechanism

The Law on the Transformation of New Scientific and Technological Achievements strengthens the dominant position of enterprises in the transformation of scientific and technological achievements. Article 18 stipulates that "R\&D institutions and universities established by the state may independently decide on the transfer, licensing or valuation of their scientific and technological achievements. However, the price should be determined through agreement pricing, listing on the technology trading market, and auction. If the price is determined by agreement, the name of the scientific and technological achievements and the price to be traded shall be publicized in the unit."

The "In-depth Implementation of the National Intellectual Property Strategy Action Plan (2014-2020)" stipulates that "establish and improve intellectual property value analysis standards and evaluation methods, improving accounting standards and related asset management systems, and promote enterprises in mergers and acquisitions, equity transfer, and foreign investment to strengthen the management of intellectual property assets in other activities." Enterprises should fully consider the actual needs of their enterprises in accordance with the relevant laws and regulations of the country. The enterprises must also be brave in reform and breakthrough and formulate a review mechanism for the transformation of scientific and technological achievements suitable for their enterprises. The evaluation mechanism should be scientific, formulate multi-level and multi-dimensional evaluation indicators, fully consider market factors, and set reasonable prices through agreements and auctions. 4.2.4 Full cultivation and utilization of intellectual property intermediary service agencies

On the one hand, we continue to cultivate and encourage the development of intellectual property intermediary service institutions through a series of policy measures such as fiscal and taxation policies, talent policies, and industry access policies. We also gradually form a benign interactive relationship based on the operation of enterprises according to law, self-protection of associations as a means, and government supervision and management as a guarantee. The training of practitioners related to intellectual property should be strengthened, and the quality and professional level of practitioners, the service capabilities, and service levels of intermediary service institutions must be comprehensively improved.

On the other hand, enterprises should learn to maximize the services provided by domestic and foreign intellectual property intermediary service agencies, such as intellectual property rights acquisition, agency services, intellectual property legal services, promotion and application services, asset evaluation services, and information services. The intellectual property strategy and management system should be improved, and technical intellectual 
property training for enterprise personnel must be conducted through the information resource and professional advantages of intermediary service institutions.

\section{References}

[1] Lu Pu, Lin Li. Research on Enterprise Stakeholder Cooperation Mode and Strategy under the Background of Open Independent Innovation [J]. Scientific Management Research, 2012, 30(5): 77-79.

[2] Zhang Ming. Research on knowledge sharing behavior of open innovation network [D]. Beijing Institute of Technology, 2015.

[3] Sha Qifu, Wang Yuanhao, Ren Yuanyuan. Policy research on the development of innovative enterprises in Anhui Province [J]. Journal of East China Jiaotong University, 2013, 30(5): 117-122.

[4] Dai Yixin, Hu Saiquan. The Influence of Open Innovation on Innovation Policy_ _ Based on the Perspective of Innovation Paradigm[J].2014,32(11):1723-1731.

[5] Li Yubi, Zhou Yongmei. Research on Intellectual Property Sharing and Benefit Distribution in Collaborative Innovation Strategy [J]. Development Research, 2013(4): 144-148.

[6] Xie Tuo, Hu Yongjun. Research on Intellectual Property Issues in Industry-University-Research Cooperation [J]. Economist, 2014(3): 24-25.

[7] Yi Ming. Open innovation model and enterprise intellectual property management reform [J]. Contemporary Economy, 2013(5): 24-25.

[8] Qin Liu. Present situation and countermeasures of intellectual property protection in Anhui Province [J]. Intellectual Property, 2010(6): 24-26.

[9] Ren Duanyang, Song Wei, Gao Xiaopei. Intellectual property benefit distribution mechanism in collaborative innovation [J]. China University Science and Technology, 2016 (1): 44-45.

[10] Chen Yu. Research on Intellectual Property Interest Distribution System [D]. Central China Normal University, 2013.

[11] Liu Jianfeng, Pan Junzhen, Yin Haiqing, Shang Yanli. Research on Intellectual Property Rights of Stateowned Enterprises in the Transformation of Scientific and Technological Achievements [J]. Chinese Invention and Patent, 2015(11):38-39.

[12] Zhang Yongcheng, Hao Dongdong. Enterprise Intellectual Property Management Strategy under Open Innovation [J]. Science and Technology Management Research, 2016(2):162-167.

[13] Li Ming. The status quo and thinking of intellectual property pledge financing in Anhui Province [J]. Anhui Science and Technology, 2015 (9): 5-7.

[14] Wang Haihua, Jiang Xucan, Xie Fuji. An empirical study on the influencing factors of knowledge sharing among organizations under the open innovation model [J]. Science and Science and Technology Management, 2013, 34(6): 85-90.

[15] Wang Ju. Possession system under open innovation: discussion based on intellectual property rights[J]. Scientific Research Management, 2010, 31(1): 153-159.

[16] Peng Zhenglong, Wang Haihua, Jiang Xucan. The effect of resource sharing on innovation performance under the open innovation model: the intermediary effect of knowledge transfer [J]. Science and Science and Technology Management, 2011, 32(1): 48-53.

[17] Shi Lei. Intellectual Property Issues and Countermeasures in my country's Science and Technology Innovation [J]. Higher Architectural Education, 2014, 23(4): 15-20.

[18] Song Hefa, Sha Kaiqing, Liu Feng. Research on Intellectual Property Policy System Driven by Innovationdriven Development and the Construction of a Powerful Intellectual Property Country [J]. Intellectual Property, 2016(2): 93-98.

[19] Yuan Xiaodong, Meng Qixun. Research on patent concentration strategy under open innovation [J]. Scientific Research Management, 2010, 31(5): 157-163.

[20] Huang Guoqun. Research on the Dilemma of Intellectual Property Collaborative Management in Open Innovation [J]. Technology Economics and Management Research, 2014(10): 22-25.

[21] Liu Xuefeng, happy. Research on intellectual property policy system to promote my country's independent innovation capability [J]. Scientific Management Research, 2014, 32(3): 21-24. 